\title{
Implementing a geographical information system to assess endemic fluoride areas in Lamphun, Thailand
}

This article was published in the following Dove Press journal: Risk Management and Healthcare Policy

\author{
Nonthaphat \\ Theerawasttanasiri ${ }^{1,2}$ \\ Surasak Taneepanichskul' \\ Wichain Pingchai ${ }^{3}$ \\ Yuwaree Nimchareon ${ }^{4}$ \\ Sangworn Sriwichai ${ }^{5}$ \\ 'College of Public Health Sciences, \\ Chulalongkorn University, Bangkok, \\ Thailand; ${ }^{2}$ Department of Health, \\ Health Promotion Center Region \\ I, Chiang Mai, Thailand; ${ }^{3}$ Mueang \\ Lamphun District Public Health \\ Office, ${ }^{4}$ Pasang District Public Health \\ Office, ${ }^{5}$ Ban Thi District Public Health \\ Office, Lamphun, Thailand
}

QR code map and GIS data

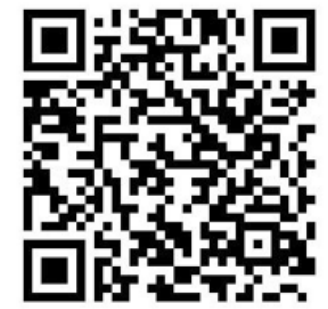

Point your SmartPhone at the code above. If you have a QR code reader the GIS data will appear.

Correspondence: Surasak

Taneepanichskul

College of Public Health Sciences,

Chulalongkorn University Institutional

Bd.3 (I0-I I FI.), Chulalongkorn 62

Phyathai Rd., Bangkok 10330, Thailand

Tel +662218 8193

Fax +6622556046

Email surasak.t@chula.ac.th
Introduction: Many studies have shown that fluoride can cross the placenta and that exposure to high fluoride during pregnancy may result in premature birth and/or a low birth weight. Lamphun is one of six provinces in Thailand where natural water fluoride (WF) concentrations $>10.0 \mathrm{mg} / \mathrm{L}$ were found, and it was also found that $>50 \%$ of households used water with high fluoride levels. Nevertheless, geographical information system (GIS) and maps of endemic fluoride areas are lacking. We aimed to measure the fluoride level of village water supplies to assess endemic fluoride areas and present GIS with maps in Google Maps.

Methods: A cross-sectional survey was conducted from July 2016 to January 2017. Purpose sampling was used to identify villages of districts with WF $>10.0 \mathrm{mg} / \mathrm{L}$ in the Mueang Lamphun, Pasang, and Ban Thi districts. Water samples were collected with the geolocation measured by Smart System Info. Fluoride was analyzed with an ion-selective electrode instrument using a total ionic strength adjustment buffer. WF $>0.70 \mathrm{mg} / \mathrm{L}$ was used to identify unsafe drinking water and areas with high endemic fluoride levels. Descriptive statistics were used to describe the findings, and MS Excel was used to create the GIS database. Maps were created in Google Earth and presented in Google Maps.

Results: We found that WF concentrations ranged between $0.10-13.60 \mathrm{mg} / \mathrm{L}$. Forty-four percent $(n=439)$ of samples were at unsafe levels $(>0.70 \mathrm{mg} / \mathrm{L})$, and. $54 \%(n=303)$ of villages and $46 \%$ $(n=79,807)$ of households used the unsafe drinking water. Fifty percent $(n=26)$ of subdistricts were classified as being endemic fluoride areas. Five subdistricts were endemic fluoride areas, and in those, there were two subdistricts in which every household used unsafe drinking water. Conclusion: These findings show the distribution of endemic fluoride areas and unsafe drinking water in Lamphun. This is useful for health policy authorities, local governments, and villagers and enables collaboration to resolve these issues. The GIS data are available at https://rive.google.com/open?id=1 mi4Pvomf5xHZ1MQjK44pdp2xXFw\&usp=sharing.

Keywords: endemic fluoride area, water supply, Google Maps, safe drinking water, GIS

\section{Introduction}

Although fluoride is good for oral health and prevents dental caries, excessive fluoride intake can result in dental fluorosis and other effects. ${ }^{1,2}$ Water is the primary means of fluoride intake in humans because fluoride is not removed from water when it is boiled or frozen, but only through distillation and filtration. ${ }^{3}$ Natural water with a high fluoride content is typically found at the foot of high mountains as a result of a geological pattern called fluoride belts. ${ }^{4}$ The US Environmental Protection Agency states that the reference dose of fluoride in the Integrated Risk Information System is $0.06 \mathrm{mg} / \mathrm{kg} / \mathrm{d} .{ }^{5}$ The World Health Organization (WHO), ${ }^{6}$ American Dental Association, ${ }^{7}$ 
US Public Health Service, ${ }^{8}$ US Environmental Protection Agency, ${ }^{9}$ and Food and Drug Administration of Thailand ${ }^{10}$ all recommend that the water fluoride (WF) level should be at $0.70 \mathrm{mg} / \mathrm{L}$ to serve as a standard reference of "safe drinking water" for the public. ${ }^{11}$ This level presents the best balance between protection against dental caries and limiting the risk of dental fluorosis.

Many studies showed that fluoride can cross the placenta and be transferred from the mother to the fetus. Exposure to high amounts of fluoride during pregnancy can result in premature birth (PTB) and low birth weight (LBW). ${ }^{12-14}$ This is of significant concern for women's and child's health across the globe, including in Thailand. ${ }^{15}$ A study from Ron et al ${ }^{16}$ reported LBW was associated with pregnant women living in endemic fluoride areas and with high WF consumption. Diouf et $\mathrm{al}^{17}$ found that high WF level was associated with increased incidence of LBW. Gurumurthy Sastry et al ${ }^{18}$ found that increases in mother's fluoride serum level put her at increased risk of giving birth prematurely and to babies of LBW. The retrospective cohort study of Hart et al ${ }^{19}$ conducted from 1993 to 2002 in Singleton in the USA reported that the incidence of PTB was associated with residential area of WF; pregnant women living in areas with $\mathrm{WF} \geq 1.0$ $\mathrm{mg} / \mathrm{L}$ had a higher incidence of PTB (6.34\%) compared to pregnant women living in areas with $\mathrm{WF}<1.0 \mathrm{mg} / \mathrm{L}(5.52 \%)$.

The incidence rate of LBW in Thailand was approximately $12 \%$ in the $1980 \mathrm{~s}$. It decreased and remained at $8 \%-9 \%$ from 1990 to 2000 . However, the target of LBW has been set as $>7 \%$ since 1991. In 2006, the Multiple Indicator Cluster Survey reported that incidence of LBW was $9.2 \%$ with no sinigficant difference in housing region or education of mother, but there was a small difference between poorer and wealthier families ( $8.5 \%$ vs $10 \%$, respectively). In some remote areas, the incidence of LBW is very high. ${ }^{20}$ The Health Promotion Centre Region 1 Chiang Mai ${ }^{21}$ reported that Lamphun had the highest incedence of LBW in Upper North. The trend of LBW appeared to be increasing from $10.98 \%$ to $11.27 \%$ from 2013 to 2015 ; Moreover, more than $50 \%$ of LBW cases were caused by PTB.

In Thailand, the source of fluoride in the water is natural rather than through fluoridation for the public. The studies of the International Water Association, ${ }^{22}$ Kongpun et $a 1,{ }^{23}$ the Intercountry Centre for Oral Health ( $\mathrm{ICOH})$ in Chiang Mai and Department of Groundwater ${ }^{24}$ all reported that Lamphun as one of six provinces with WF over $10 \mathrm{mg} / \mathrm{L}$, and, moreover, stated that $>50 \%$ of households used unsafe drinking water. A study by Chuah et $\mathrm{al}^{25}$ found that groundwater in Lamphun contains fluoride of at least $1.5 \mathrm{mg} / \mathrm{L}$. Leatherwood et al stated that a high incidence of dental fluorosis in pregnancy was found in the North of Thailand, including in Lamphun, which was caused the consumption of large quantities of $\mathrm{WF}^{26}$

Most of the fluoride research in the province of Lamphun focused on dental fluorosis and WF in groundwater in deep as well as shallow wells. There is no documentation regarding the WF of village water supplies, which is considered as the main source of fluoride exposure of villagers. Regardless, in the absence of geographical information system (GIS) data and geovisual maps, fluoride in community water supplies and endemic fluoride areas are the responsibility of local relevant agencies to resolve. The aims of this study were to assess the fluoride level of community water supplies and to present GIS data with geovisual maps of endemic fluoride areas on Google Maps.

The findings of this study may be useful for relevant agencies such as health policy authorities and the local government, for villagers and for planning health education for people in endemic fluoride areas and for preventing and reducing the fluoride exposure or removing fluoride from the village water supplies (or alternatively, use other sources for safe drinking water). The results of the GIS and geovisual maps on Google Maps may increase the accessibility to fluoride information through internet terminals. This would hopefully increase awareness and collaboration to help resolve the problems.

\section{Materials and methods Study design}

This cross-sectional study was part of a pregnancy-birth cohort study: "The association between maternal fluoride level and preterm delivery and LBW among pregnant women at endemic fluoride areas in Lamphun province, Thailand." The survey was conducted from July 2016 to January 2017. The study protocol was approved by the Ethical Research Review Committee of Lamphun Hospital (Ethic LPN 50/2559) and The Ethics Research Review Committee of Research Involving Human Research participants, Health Science Group Chulalongkorn University, (COA no. 154/2016).

\section{Study areas}

The province of Lamphun is subdivided in 8 districts, 51 subdistricts, and 621 villages. The study areas were purposively selected because WF levels in groundwater were found to be over $10.0 \mathrm{mg} / \mathrm{L}$, and more than $50 \%$ of households used unsafe drinking water, when surveyed in 2010, and most of the villages that used unsafe drinking water were from the 
districts of Mueang Lamphun, Pasang, and Ban Thi. The process of selection is presented in Figure 1.

\section{Assessment of WF and data analysis}

Water samples of $30 \mathrm{~mL}(\mathrm{~N}=439)$ were collected in plastic bottles and sent to the laboratory of $\mathrm{ICOH}$, Chiang Mai, Thailand. ${ }^{27}$ Samples were analyzed using ion-selective electrodes, which is the standard method for the examination of water and wastewater by ORION model 4-star (16th edition ${ }^{28}$ ) after use of a total ionic strength adjustment buffer. A level of WF $>0.7$ $\mathrm{mg} / \mathrm{L}$ was used to identify unsafe drinking water and endemic areas. Descriptive statistics were used to describe the results. Because the WF value was not evenly distributed, the median rather than the mean was used for calculating the average of the WF level. Percentages were used to analyze villages in endemic areas and/or household exposure to high fluoride water and to determine unsafe drinking water in each of the subdistrict.

\section{GIS data, geolocation, and geovisual map management}

Microsoft Excel was used to create a GIS database and interpret the data of village water supply, geolocation of water supplies, and the fluoride levels. The Smart System Info, ${ }^{29}$ a free global positioning system (GPS) application for Android mobile device, was used to measure the geolocation of the water supplies. The data boundaries of the Lamphun province, districts, and subdistricts, including the Keyhole Markup Language (KML) and Keyhole Markup Language Zipped (KMZ) files, were downloaded from the GADM database of Global Administrative Areas (GADM.org). ${ }^{30}$ Google Earth ${ }^{31}$ was used to create and manage KML and KMZ files as geovisual map layers. The data of all layers were imported and presented in Google Maps. ${ }^{32}$

The KML and KMZ files were classified as follows:

1) Type of water supplies was classified as village taps, waterworks, village filters, water dispensers, or bottled water.
2) WF level of water supplies were classified into five groups - 1) WF: $\leq 0.7 \mathrm{mg} / \mathrm{L}, 2) \mathrm{WF}: 0.71-0.99 \mathrm{mg} / \mathrm{L}, 3)$ WF: $1.0-4.0 \mathrm{mg} / \mathrm{L}, 4) \mathrm{WF}: 4.1-10.0 \mathrm{mg} / \mathrm{L}$, and 5) WF: 10.1-13.0 mg/L, respectively. The blue legend was used in the maps and dark blue was used to indicate levels of fluoride.

3) Drinking water was classified as water with fluoride $\leq 0.7$ $\mathrm{mg} / \mathrm{L}$, which was considered to be safe drinking water (green), and WF $>0.7 \mathrm{mg} / \mathrm{L}$, which was considered as unsafe drinking water (red).

4) Average WF of subdistricts were as follows: WF $\leq 0.7$ $\mathrm{mg} / \mathrm{L}$ (green), WF between 0.71 and $0.99 \mathrm{mg} / \mathrm{L}$ (yellow), WF between 1.0 and $0.4 \mathrm{mg} / \mathrm{L}$ (orange), and $\mathrm{WF}>4.0$ $\mathrm{mg} / \mathrm{L}$ (red).

5) Percentages of villages with endemic fluoride areas and household exposure to fluoride was given a red legend, with the intensity of the color range increasing from light to dark red depending on the level.

\section{Results}

\section{Water source and water supply system}

There are two primary sources of the water supply in Lamphun: the groundwater and the surface water systems. The water treatment system depends on the type of water supply system and available budget. There are five water supply systems:

1. Village taps, in which most of the water is sourced from groundwater. The treatment system itself depends on the budget of administrations. Some village taps have the same treatment system as the waterworks, others include parts of the treatment process, and a smaller number only have water which is pumped to a storage tank and is distributed through a pipeline. The administration system is made up of the local municipal government, Subdistrict Administration Organization, and a village- or community-based committee.

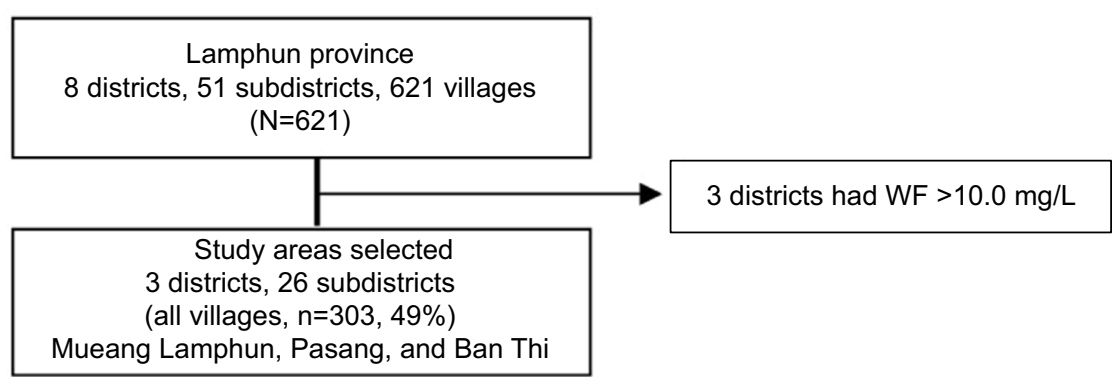

Figure I The process of study areas selection.

Abbreviation: WF, water fluoride. 
2. Village filter: This water is sourced from village taps. The administration system is operated by village- or community-based committees. The treatment systems consist of reverse osmosis (RO) and ultraviolet or ozone treatments. Households can access water by purchasing and transporting water in containers to their home by themselves, although some villages offer a home delivery system.

3. Water dispensers: The water is sourced from village taps or groundwater in the form of shallow wells. Most are set up as private businesses. The treatment systems include RO and ultraviolet or ozone treatments. Households can access water by purchasing containers and bringing them home themselves.

4. Bottled water (local brands): This water is sourced from groundwater. Most are set up as private businesses. The treatment systems include RO and ultraviolet or ozone treatments. After treatment, the water will be kept in 20-L plastic buckets or plastic bottles sized $750 \mathrm{~mL}$ and delivered to the home of customers.

5. Waterworks: The water comes from the Mae Kuang River and is operated by the provincial waterworks authority. The treatment systems consist of rapid mixing, slow mixing, sedimentation filtration, chlorination, and storage, and distribution is through a system of pipelines. This method is only used in the Mueang Lamphun district.

\section{WF level and unsafe drinking water}

There were five types of village water supplies, comprising village taps $(81.6 \%)$, village filters $(12.5 \%)$, water dispensers $(2.7 \%)$, bottled water $(2.1 \%)$, and waterworks $(1.1 \%)$, respectively. The WF range was $0.10-13.60 \mathrm{mg} / \mathrm{L}$. The maximum fluoride level was $13.60 \mathrm{mg} / \mathrm{L}$ in village taps (Table 1). The average (median) WF levels were ranked in the following order: waterworks $(0.82 \mathrm{mg} / \mathrm{L})$, village taps $(0.61 \mathrm{mg} / \mathrm{L})$, bottled water $(0.38 \mathrm{mg} / \mathrm{L})$, village filters $(0.26 \mathrm{mg} / \mathrm{L})$, and water dispensers $(0.18 \mathrm{mg} / \mathrm{L})$ (Figure 2$)$.
Of the 439 samples, $44.2 \%$ (194) contained unsafe drinking water. Unsafe drinking water was the highest for village taps $(37.8 \%)$, followed by village filters $(4.1 \%)$, waterworks and water dispensers $(0.9 \%)$, and, finally, bottled water $(0.5 \%)$. Of 79,807 households, $79.0 \%$ used water from village taps, $45.6 \%$ had unsafe drinking water, and $34.9 \%$ used unsafe drinking water from village taps (Table 2).

\section{Endemic fluoride areas}

The percentage of villages with endemic areas was high in the Ban Thi (75.0\%), Mueang Lamphun (53.7\%), and Pasang (45.6\%) districts, respectively. The percentage of households using unsafe drinking water was highest in the Ban Thi (63.9\%), Mueang Lamphun (49.8\%), and Pasang (31.9\%) districts. Overall, of 303 villages, $54 \%$ could be considered endemic areas; of 79,807 households, 45.6\% used unsafe drinking water (Table 3).

At the subdistrict level, the maximum WF level was 13.60 $\mathrm{mg} / \mathrm{L}$ in Pasak, with the highest average fluoride level of 7.90 $\mathrm{mg} / \mathrm{L}$ observed in Ban Klang $(7.90 \mathrm{mg} / \mathrm{L})$ in the Mueang Lamphun district (Figure 3).

Of a total of 26 subdistricts, $50 \%$ were endemic fluoride areas. In five subdistricts all villages were endemic fluoride areas, namely Makhuea Chae, Ban Klang and Pa Sang, and in those, two subdistricts, namely Ban Paen and Nai Mueang, every household used unsafe drinking water (Table 4).

\section{GIS data and geovisual map layers}

The GIS data and geovisual map were presented in Google Maps and are available at https://drive.google.com/open? $\underline{\mathrm{id}=1 \mathrm{mi} 4 \mathrm{P} v o m f 5 \times H Z 1 M Q j K 44 p d p 2 \times X F w \& u s p=\text { sharing. }}$

\section{Layers of geovisual maps}

1. Study area: The boundaries of Lamphun province and the Mueang Lamphun, Pasang, and Ban Thi districts;

2. A subdistrict of the Mueang Lamphun district;

3. A subdistrict of the Pasang and Ban Thi districts.

Table I Percentage of water sample by types and fluoride level (minimum, maximum, and median)

\begin{tabular}{|c|c|c|c|c|}
\hline \multirow[t]{2}{*}{ Type of water } & \multirow{2}{*}{$\begin{array}{l}\text { Number of sample } \\
(\mathrm{N}=439), \mathrm{n}(\%)\end{array}$} & \multicolumn{3}{|c|}{ Fluoride level (mg/L) } \\
\hline & & Minimum & Maximum & Median \\
\hline \multicolumn{5}{|l|}{ Water supply } \\
\hline Village tap & $358(81.6)$ & 0.10 & 13.60 & 0.61 \\
\hline Waterworks & $5(I . I)$ & 0.26 & 0.83 & 0.82 \\
\hline \multicolumn{5}{|l|}{ Drinking water } \\
\hline Village filter & $55(12.5)$ & 0.10 & 3.99 & 0.26 \\
\hline Water dispenser & $12(2.7)$ & 0.10 & 12.30 & 0.18 \\
\hline Bottled water & $9(2.1)$ & 0.10 & 3.08 & 0.38 \\
\hline Total & $439(100)$ & 0.10 & 13.60 & 0.54 \\
\hline
\end{tabular}




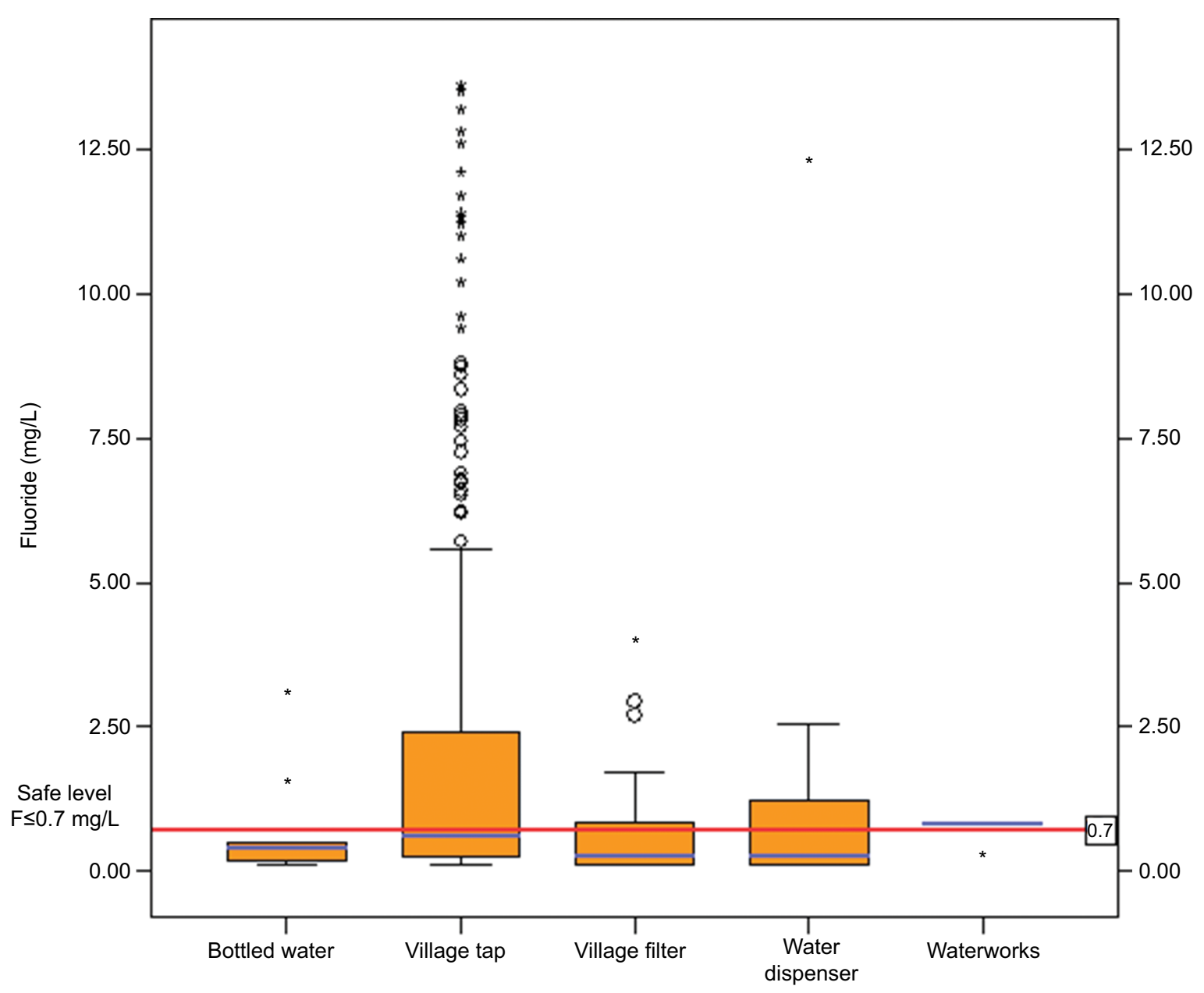

Type of water

Figure 2 Levels of fluoride found in different water sources.

Table 2 Percentage of unsafe drinking water and data on household usage of unsafe drinking water

\begin{tabular}{|c|c|c|c|c|}
\hline \multirow[t]{2}{*}{ Type of water } & \multicolumn{2}{|c|}{ Water sample $(\mathrm{N}=439)$} & \multicolumn{2}{|l|}{ Household } \\
\hline & Total & $\begin{array}{l}\text { Unsafe drinking } \\
\text { water (\%) }\end{array}$ & Total & $\begin{array}{l}\text { Unsafe drinking } \\
\text { water (\%) }\end{array}$ \\
\hline \multicolumn{5}{|l|}{ Water supply } \\
\hline Village tap & $358(81.6)$ & $166(37.8)$ & $63,073(79.0)$ & $27,842(34.9)$ \\
\hline Waterworks & $5(1.1)$ & $4(0.9)$ & $6,096(7.6)$ & $6,096(7.6)$ \\
\hline \multicolumn{5}{|l|}{ Drinking water } \\
\hline Village filter & $55(12.5)$ & $18(4.1)$ & 9,068 (II.4) & $2,213(2.8)$ \\
\hline Water dispenser & $12(2.7)$ & $4(0.9)$ & $\mathrm{I}, 163(1.5)$ & $177(0.2)$ \\
\hline Bottled water & $9(2.1)$ & $2(0.5)$ & $407(0.5)$ & $94(0.1)$ \\
\hline Total & $439(100)$ & $194(44.2)$ & $79,807(100)$ & $36,422(45.6)$ \\
\hline
\end{tabular}

Table 3 The percentage of villages with endemic areas and data on household usage of unsafe drinking water by district

\begin{tabular}{|c|c|c|c|c|}
\hline \multirow[t]{2}{*}{ District } & \multicolumn{2}{|c|}{ Village $(\mathbf{N}=303)$} & \multicolumn{2}{|c|}{ Household } \\
\hline & Total & Endemic area (\%) & Total & Unsafe drinking water (\%) \\
\hline Mueang Lamphun & 177 & $95(53.7)$ & 46,404 & $23,121(49.8)$ \\
\hline Pasang & 90 & $41(45.6)$ & 25,162 & 8,032 (31.9) \\
\hline Ban Thi & 36 & $27(75)$ & 8,241 & $5,269(63.9)$ \\
\hline Total & 303 & 194 (44.2) & 79,807 & $36,422(45.6)$ \\
\hline
\end{tabular}




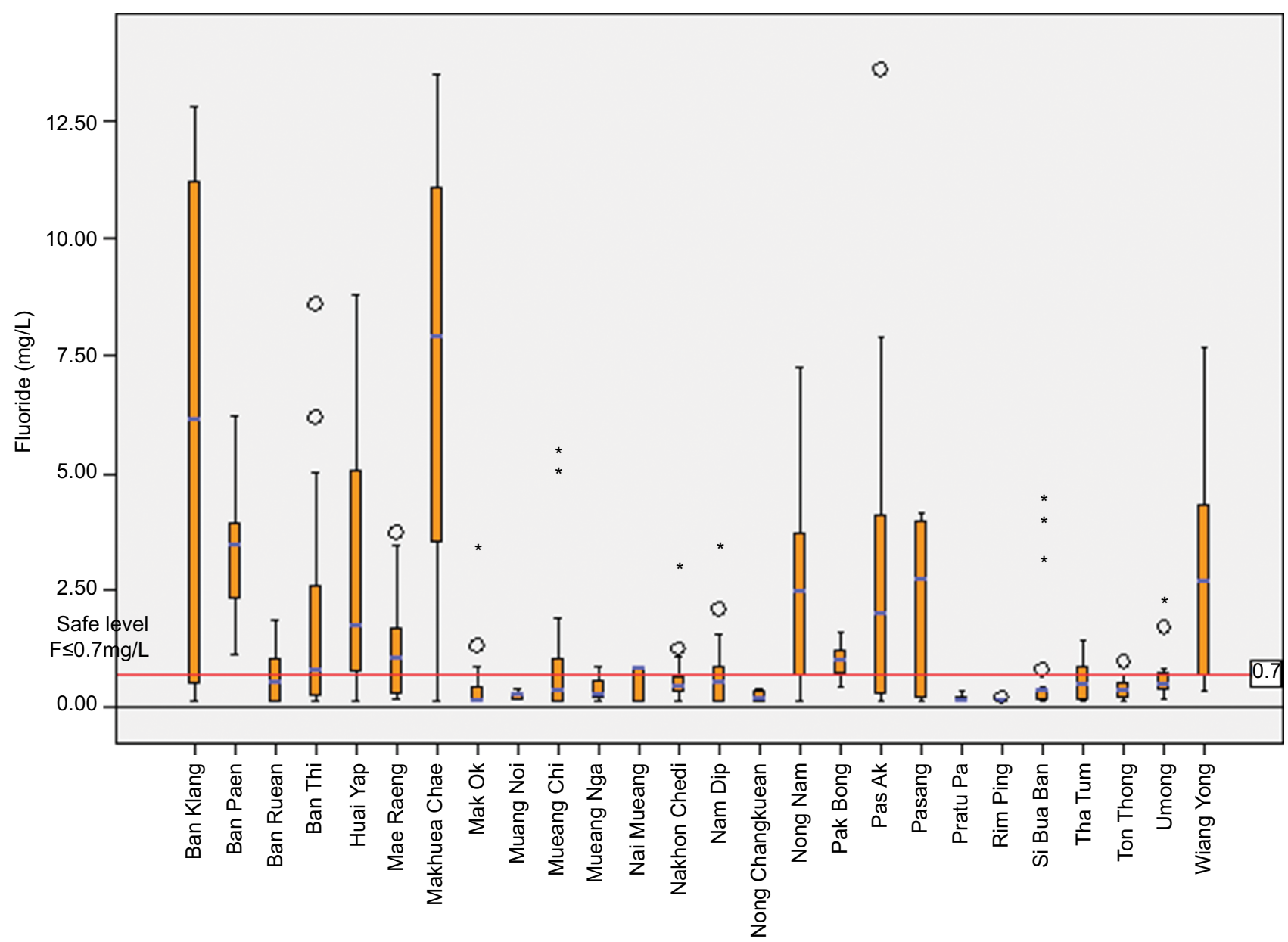

Sub district

Figure 3 Levels of fluoride found in water sources within subdistrict.

\section{Layers of GIS data of WF level}

4. Types of water supplies;

5. Fluoride levels of water supplies;

6. Unsafe drinking water in the Mueang Lamphun district;

7. Unsafe drinking water in the Pasang and Ban Thi districts.

\section{Layers of geovisual maps of fluoride analysis}

8. Average WF level of subdistricts (median)

9. Percentage of household exposed to fluoride in subdistricts;

10. Percentage of village with endemic fluoride in subdistricts.

The geovisual map and GIS data can be used separately or the layers can be mixed together. An example of this shown in Figures 4 and 5.

\section{Discussion}

The findings show that nearly half of all households in Lamphun used water with high fluoride, and this was mostly from village tap water sourced from groundwater. The maximum WF was $13.6 \mathrm{mg} / \mathrm{L}$ - up to 19 times the level usually found in safe drinking water. It confirms the results of previous studies of the International Water Association in $2006,{ }^{22}$ and $\mathrm{ICOH},{ }^{24}$ which reported that Northern Thailand had the areas with the highest concentrations of fluoride in the groundwater. Most people use water from underground sources, such as groundwater, deep wells, and shallow wells, for consumption via drinking and cooking. Chuah et $\mathrm{al}^{25}$ reported that groundwater in Lamphun contained fluoride with a concentration of at least $1.5 \mathrm{mg} / \mathrm{L}$. This would imply that people are residing in endemic fluoride areas exposed to high WF, including pregnant women. However, to determine the WF result in LBW and PTB, the level of fluoride exposure in pregnant women and an assessment of LBW and PTB should be examined in depth.

Similar to the study of the $\mathrm{WHO}^{4}$ and Kongpun et al, ${ }^{23}$ the results of the GIS data and geovisual maps show that the endemic fluoride areas are distributed following a geological pattern of the fluoride belt. These results contribute to a 
Table 4 Percentage of villages with an endemic area and percentage of households using unsafe drinking water by subdistricts

\begin{tabular}{|c|c|c|c|c|c|c|}
\hline \multirow[t]{2}{*}{ District/subdistrict } & \multirow{2}{*}{$\begin{array}{l}\text { Range } \\
\text { (mg/L) }\end{array}$} & \multirow{2}{*}{$\begin{array}{l}\text { Median } \\
\text { (mg/L) }\end{array}$} & \multicolumn{2}{|c|}{ Villages $(\mathrm{N}=303)$} & \multicolumn{2}{|c|}{ Household } \\
\hline & & & Total & $\begin{array}{l}\text { Endemic } \\
\text { areas (\%) }\end{array}$ & Total & $\begin{array}{l}\text { Unsafe drinking } \\
\text { water (\%) }\end{array}$ \\
\hline \multicolumn{7}{|l|}{ Mueang Lamphun } \\
\hline Makhuea Chae ${ }^{\mathrm{a}}$ & $1.10-13.50$ & 7.89 & 21 & $21(100)$ & 4,547 & $4,387(96.5)$ \\
\hline Ban Klanga & $3.90-12.80$ & $7.90^{\mathrm{b}}$ & 12 & $12(100)$ & 2,409 & $\mathrm{I}, 879(78)$ \\
\hline Ban Paen ${ }^{\mathrm{a}, \mathrm{c}}$ & $1.10-6.24$ & 3.43 & 9 & $9(100)$ & 1,885 & $1,885(100)$ \\
\hline Nai Mueang ${ }^{c}$ & $0.82-0.83$ & 0.83 & 17 & $17(100)$ & 6,096 & $6,096(100)$ \\
\hline Pa Sak & $0.10-13.60^{d}$ & 1.97 & 18 & $12(66.7)$ & 3,846 & $2,520(65.5)$ \\
\hline Nong Nam & $0.10-7.26$ & 2.44 & 9 & $6(66.7)$ & 696 & $523(75.1)$ \\
\hline Wiang Yong & $0.40-7.70$ & 1.86 & 8 & $5(62.5)$ & 1,659 & $\mathrm{I}, 008(60.8)$ \\
\hline Mueang Chi & $0.10-5.40$ & 0.35 & 14 & $5(35.7)$ & 2,877 & $\mathrm{I}, 3 \mathrm{I} 5(45.7)$ \\
\hline Umong & $0.18-2.23$ & 0.48 & 11 & $3(27.3)$ & 3,717 & $\mathrm{I}, 302(35)$ \\
\hline Si Bua Ban & $0.10-4.45$ & 0.35 & 12 & $3(25)$ & 5,323 & $942(17.7)$ \\
\hline Mueang Nga & $0.10-0.85$ & 0.27 & 10 & $\mathrm{I}(10)$ & 4,236 & 479 (II.3) \\
\hline Ton Thong & $0.12-0.96$ & 0.43 & 9 & I (9.1) & 3,279 & $752(22.9)$ \\
\hline Pratu $\mathrm{Pa}$ & $0.10-0.33$ & 0.14 & II & $0(0)$ & $\mathrm{I}, 868$ & $0(0)$ \\
\hline Rim Ping & $0.10-0.21$ & 0.10 & 10 & $0(0)$ & 2,731 & $0(0)$ \\
\hline Nong Chang Khuen & $0.13-0.38$ & 0.15 & 6 & $0(0)$ & 1,235 & $0(0)$ \\
\hline Total & $0.10-13.60$ & 0.40 & 177 & $95(53.7)$ & 46,404 & $23,088(49.8)$ \\
\hline \multicolumn{7}{|l|}{ Pasang } \\
\hline Pa Sang ${ }^{c}$ & $2.7 I-4.15$ & 3.99 & 5 & $5(100)$ & 2,290 & $1,525(66.6)$ \\
\hline Pak Bong & $0.58-1.59$ & 1.19 & 5 & $4(80)$ & 2,185 & $1,459(66.8)$ \\
\hline Mae Raeng & $0.18-3.45$ & 1.02 & 11 & $7(63.6)$ & 2,921 & $\mathrm{I}, 307(44.7)$ \\
\hline Ban Ruean & $0.27-1.84$ & 0.96 & 8 & $5(62.5)$ & 2,230 & $758(34)$ \\
\hline Tha Tum & $0.10-1.30$ & 0.63 & 14 & $7(50)$ & 4,092 & $869(21.2)$ \\
\hline Nakhon Chedi & $0.16-2.94$ & 0.68 & 13 & $5(38.5)$ & 3,080 & $473(15.4)$ \\
\hline Nam Dip & $0.10-3.40$ & 0.51 & 17 & $6(35.3)$ & 2,916 & $6 \mid 7(2 \mid .2)$ \\
\hline Makok & $0.10-3.32$ & 0.33 & 9 & $2(22.2)$ & 2,808 & $350(12.5)$ \\
\hline Muang Noi & $0.16-0.39$ & 0.26 & 8 & $0(0)$ & 2,640 & $0(0)$ \\
\hline Total & $0.10-4.15$ & 1.35 & 90 & $4 I(45.6)$ & 25,162 & $7,358(29.2)$ \\
\hline \multicolumn{7}{|l|}{ Ban Thi } \\
\hline Huai Yap & $0.6 I-8.80$ & 1.23 & 16 & I3 (8I.2) & 5,424 & $2,813(51.9)$ \\
\hline Ban Thi & $0.12-8.60$ & 4.42 & 20 & $14(70)$ & 2,817 & $2,274(80.7)$ \\
\hline Total & $0.12-8.80$ & 0.62 & 36 & $27(75)$ & 8,241 & 5,087 (61.7) \\
\hline Total & $0.10-3.60$ & 0.54 & 303 & $163(53.8)$ & 79,807 & $35,533(44.5)$ \\
\hline
\end{tabular}

Notes: aSubdistrict where every village was an endemic area bhighest average fluoride level 'subdistrict where every village and every household used unsafe drinking water, dmaximum fluoride level.

better understanding of the distribution of fluoride to local policymakers and administrators of the village water supply and enable the promotion of discussion on the best way to provide safe drinking water for the community.

\section{Strength of study}

In this study, GIS technology and Google Maps were used to present and assess results that will be useful for the relevant agencies or internet users to access and distribute information through their web browsers or smart phone devices from anywhere.

\section{Limitations and uncertainties}

Our study clearly has some limitations. The boundary data in this study (version 2.8, November 2015) resulted in an incorrect overlap of geographical boundaries on Google
Maps. Any new version should be updated accordingly. The Smart System Info program for measuring GPS was suitable for Android phone devices only. The dislocation of GPS data caused by the measuring process is based on the brand and model of the mobile phones as well as on the signal strength of the network providers. To reduce error in the result, it should be possible for the application to be refreshed for a new area to access the correct location. A free version of Google Maps supports 10 layers per map; so, more than 10 layers should be separated into more than one map.

\section{Conclusion}

The findings of this study will be useful for health policy authorities and local governments to collaborate on resolving the problem. In addition, they will contribute to planning for 


\section{A}

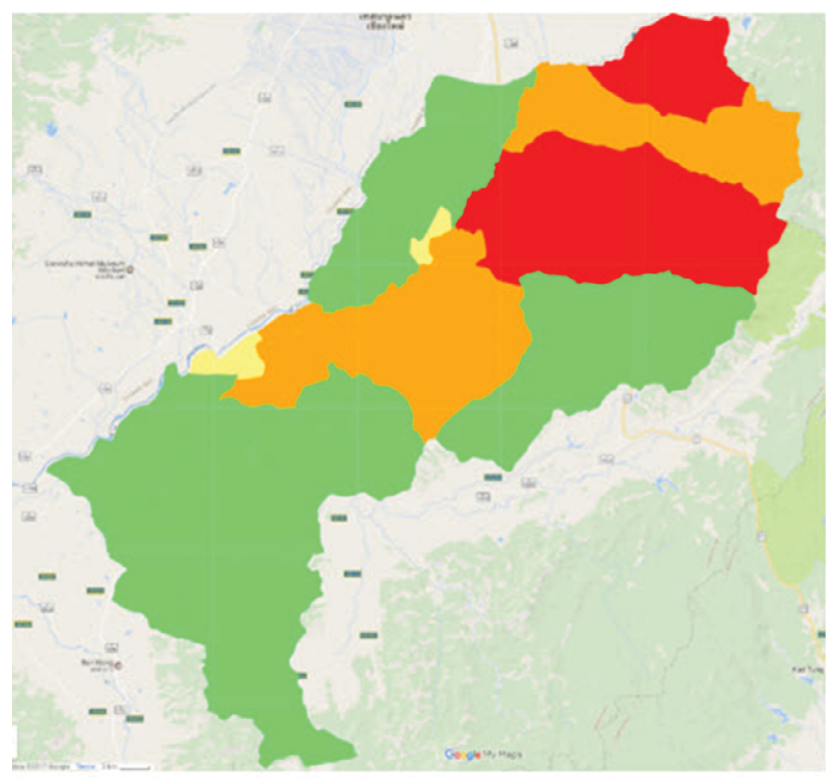

B

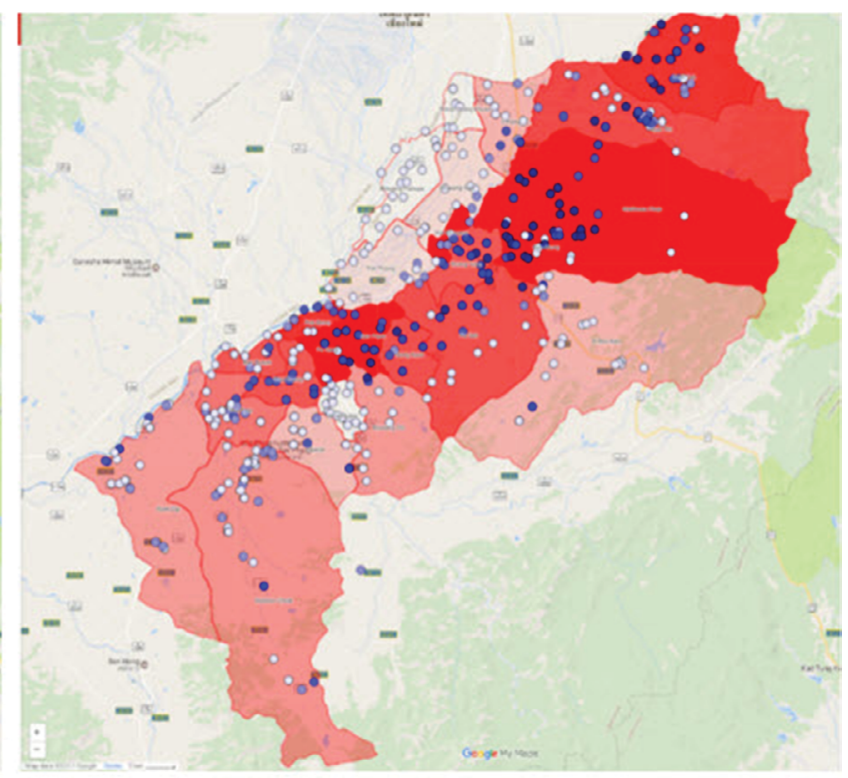

Figure 4 (A) Layer 8, average WF level of sub districts (median); (B) mix of layer 5 and layer 9, percentage of households exposed to fluoride in subdistricts. Abbreviation: WF, water fluoride.

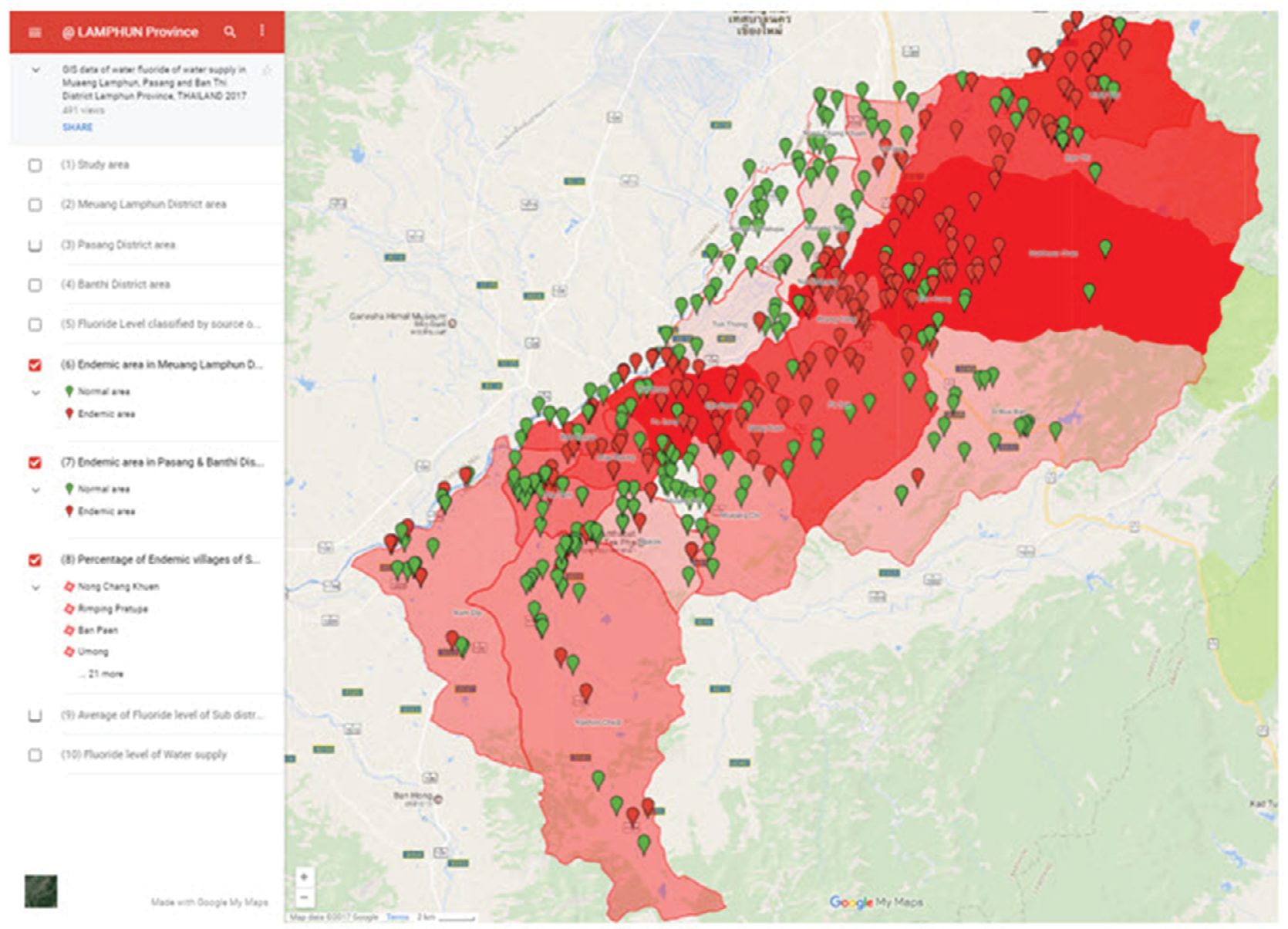

Figure 5 Mix of layer (10) percentage of the village with endemic fluoride in subdistricts, layer (7) unsafe drinking water in Mueang Lamphun district, and layer (6) unsafe drinking water in Pasang and Ban Thi district. 
health education for prevention and reduction of fluoride exposure of people in endemic areas, including increasing awareness and participation of individuals in resolving the problem.

\section{Acknowledgments}

The authors would like to thank the Lamphun Provincial Public Health Office, Lamphun Hospital, Pasang Hospital, Ban Thi Hospital, Subdistrict Health Promotion Hospital in Mueang Lamphun, Pasang, and Ban Thi districts, and $\mathrm{CIOH}$ Chiang Mai, all of whom made this study possible. The authors also thank Mrs. Marina Moore, College of Public Health Sciences, Chulalongkorn University.

This study was supported by the 90th Anniversary of the Chulalongkorn University Fund and the National Research Council of Thailand (NRCT).

\section{Disclosure}

The authors report no conflicts of interest in this work.

\section{References}

1. Namkaew M, Wiwatanadate P. Association of fluoride in water for consumption and chronic pain of body parts in residents of San Kamphaeng District, Chiang Mai, Thailand. Trop Med Int Health. 2012;17(9):1171-1176.

2. Chaiwong S, Titimoon S, Hirunbannasan P, Wongcharoen W. Blood and urine fluoride and iodine, and blood thyroid functions tests in 1st trimester pregnant women in Phayao Province, Thailand. In: XXXII Conference of the International Society for Fluoride Research (ISFR); November 25-28, 2014; Chiang Mai, Thailand.

3. Fawell J, Bailey K, Chilton J, Dahi E, Fewtrell L, Magara Y. Fluoride in Drinking-Water. London: World Health Organization, IWA Publishing; 2006:97-117.

4. World Health Organization. Fluorides and Oral Health. Report of a WHO Expert Committee on Oral Health Status and Fluoride Use. Geneva: World Health Organization; 1994.

5. Connett P, Beck J, Micklem HS. The Case Against Fluoride: How Hazardous Waste Ended Up in Our Drinking Water and The Bad Science and Powerful Politics That Keep It There. White River Junction, Vermont: Chelsea Green Publishing; 2010.

6. World Health Organization. Basic Methods for Assessment of Renal Fluoride Excretion in Community Prevention Programmes for Oral Health. Geneva: World Health Organization; 2014.

7. American Dental Association. Oral Health Topics: Fluoride Supplements, Facts about Fluoride. Chicago: American Dental Association; 2016. Available from: http://www.ada.org/en/member-center/oral-healthtopics/fluoride-supplements\#dosschedule. Accessed February 6, 2016.

8. U.S. Department of Health and Human Services Federal Panel on Community Water Fluoridation. U.S. Public Health Service Recommendation for fluoride concentration in drinking water for the prevention of dental caries. Public Health Rep. 2015;130(4):318-331.

9. United States Environmental Protection Agency. Six-Year Review of Drinking Water Standards. Washington, DC: United States Environmental Protection Agency; 2016. Available from: https://www.epa.gov/sites/production/ files/2014-12/documents/815f09002.pdf. Accessed February 7, 2016.

10. Food and Drug Administration of Thailand, Bureau of Dental Health, Institute of Nutrition Mahidol University. Situation of Fluoride Concentration in Bottled Water; 2008.
11. World Health Organization. Fact Sheet: Drinking-Water. Geneva: World Health Organization; 2017. Available from: http://www.who.int/mediacentre/factsheets/fs391/en. Accessed February 18, 2016.

12. MacArthur JD. Fluoride, Premature Birth and Impaired Neurodevelopment: A Global Review of Recent Laboratory, Clinical, and Ecological Evidence that Fluoride Is a Significant Risk Factor for Premature Birth and Long-Term Neurological Disabilities. Port Townsend: Townsend Letter: The Examiner of Alternative Medicine; 2013.

13. Lardon JP, Vincent R. Fluoride, and pregnancy. Should fluoride be prescribed for pregnant women? Rev Odontostomatol (Paris). 1986;15(1):31-35.

14. Chlapowska J, Opydo-Szymaczek J. Dietary and hygienic aspects of fluoride exposure in pregnant women. Ann Acad Med Stetin. 2004;50(Suppl 1):19-22.

15. World Health Organization. Preterm Birth Fact Sheet no. 363; 2015. Available from: http://www.who.int/mediacentre/factsheets/fs363/en/. Accessed February 18, 2016.

16. Ron M, Singer L, Menczel J, Kidroni G. Fluoride concentration in amniotic fluid and fetal cord and maternal plasma. Eur J Obstet Gynecol Reprod Biol. 1986;21(4):213-218.

17. Diouf M, Cisse D, Lo CMM, Ly M, Faye D, Ndiaye O. Pregnant women living in areas of endemic fluorosis in senegal and low birth weight newborns: case-control study. Revue Epidémiol de Santé Publique. 2012;60:103-108.

18. Gurumurthy Sastry M, Mohanty S, Aparna VB, Mishra AK, Pragna Rao. Association of higher maternal serum fluoride with adverse fetal outcomes. Int J Med Public Health. 2011;1(2):13-17.

19. Hart R, Feelemyer J, Gray C, et al. Relationship between municipal water fluoridation and preterm birth in upstate New York. Presented at: Annual Meeting of the American Public Health Association (APHA); November 9; 2009; Philadelphia, Pennnsylvania.

20. Winichagoon $P$. Thailand nutrition in transition: situation and challenges of maternal and child nutrition. Asia Pacific J Clin Nutr. 2013;22(1): $6-15$.

21. Health Promotion Center Region1 Chiang Mai DOH. Mother and Child Health Dataset; 2015. Chaing Mai: Health Promotion Center Region 1 Chiang Mai; 2016:45-49.

22. International Water Association, World Health Organization. Fluoride in Drinking-Water. Cornwall: TJ International (Ltd); 2006.

23. Kongpun M, Choompolkul W, PromsakhaNaSakolnakorn J. Fluorotoxicosis Management in Chiang Mai and Lumphoon Territory; 2007.

24. ICOH. Research \& Report; 2010 . Available from: http://203.157.65.18/ doh_info/web/uploads/pdf_961/YdhP47N86DNgcbjbzF1mu4XS505wKNYx6GiL1Xn01N7jvZp8KYX2-1LMnEAAP0AcN0GNU2uiYDtwNLCHcO0zqTUzp43r2dVnlAiV.pdf. Accessed 7 Feb, 2016.

25. Chuah CJ, Lye HR, Ziegler AD, Wood SH, Kongpun C, Rajchagool S. Fluoride: a naturally-occurring health hazard in drinking-water resources of Northern Thailand. Sci Total Environ. 2016;545-546:266-279.

26. Leatherwood EC, Burnett GW, Chandravejjsmarn R, Sirikaya P. Dental caries And dental fluorosis in Thailand. Am J Public Health Nations Health. 1965;55(11):1792-1799.

27. World Health Organization. Provision of technical advice: TISAB. In: Baez RJ, Petersen PE, Marthaler TM, editors. Basic Methods for Assessment of Renal Fluoride Excretion in Community Prevention Programmes for Oral Health. Geneva: World Health Organization. 2014:67-78.

28. Chamnanprai S. Analysis Of fluoride concentration in drinking water; 2000. Available from: http://slideplayer.in.th/slide/2149799/. Accessed Feb 18, 2016.

29. Smart System Info [computer program]. Version 1.3, 2013.

30. Global Administrative Areas: Thailand Boundaries; 2014. Available from: http://www.gadm.org/country. Accessed December 15, 2016.

31. Google Earth [computer program]. Version 7.1.8.3036 (32-bit), 2016.

32. Google Inc. Google Maps; 2017. Available from: https://www.google. com/maps. 
Risk Management and Healthcare Policy is an international, peer-reviewed, open access journal focusing on all aspects of public health, policy, and preventative measures to promote good health and improve morbidity and mortality in the population. The journal welcomes submitted papers covering original research, basic science, clinical and epidemiological studies, reviews and evaluations, guidelines, expert opinion and commentary, case reports and extended reports. The manuscript management system is completely online and includes a very quick and fair peerreview system, which is all easy to use. Visit http://www.dovepress.com/ testimonials.php to read real quotes from published authors.

Submit your manuscript here: https://www.dovepress.com/risk-management-and-healthcare-policy-journal 